\title{
北海道南西部の群発地震活動
}

\author{
北海道大学理学部地震予知観測地域センター 本谷義信 \\ (昭和 55 年 12 月 13 日受理)
}

\section{On Earthquake Sequences in the Oshima Peninsula, Southwestern Part of Hokkaido}

\author{
Yoshinobu MoTOYA \\ Research Center for Earthquake Prediction, Faculty of Science, \\ Hokkaido University
}

(Received December 13, 1980)

Some features on earthquake sequences occurred in the Oshima peninsula, southwestern part of Hokkaido are appreciated in this paper. First data on rather remarkable earthquake sequences for 1900-1980 were briefly summarized, then recent microearthquake series observed by a new seismic network of the Research Center for Earthquake Prediction (RCEP), Hokkaido University, were studied.

Seismicity near the ESH station during the period from July 1976 to October 1978 was investigated in detail. While seismic activity was low in the first one year, it became high and 8 series of earthquakes were recognized in the last two years. A premonitory seismic activity which may be closely associated with the forthcoming main earthquake sequence was found in some cases. It has been pointed out that the pattern of earthquake sequences is classified into three types: main shock-aftershock series, foreshock-main shock-aftershock series and swarm, and that high degree of fracturing in mechanical structure of the uppercrust in the Oshima peninsula is deduced from the frequent occurrence of earthquakes preceded by foreshocks and earthquake swarms. However, the 8 sequences investigated showed not only typical swarm type but also other types, including transient or complex ones. Time series pattern of events in the sequences was examined with relation to variation of locations, magnitudes, amplitude ratios of $\mathrm{P}$ and $\mathrm{S}$ waves, waveforms and so on. The examination shows that there is no common characteristic between the above parameters and the sequence type. Complicated features of earthquake sequences may imply that the degree of stress concentration which may be attributed to heterogeneity in mechanical structure of the uppercrust is different even in a limited region in the Oshima peninsula.

It has been proposed that there is a tectonic line along the northeastern margin of the Oshima peninsula, connecting two active volcanoes, Komagatake and Esan. Earthquakes occurring in the part from Komagatake to ESH may by related to this tectonic line, while no seismic evidence was found in the part from ESH to Esan.

\section{§1. はじめに}

群発地震はそれだけで大規模な地震被害を出すことはあまりないが，局地的にせよ有感地震 が頻発すると人心不安をひき起し社会的関心をあつめることがあるし，火山噴火や大地震の発 
生との関連が考えられることもあるので，その特性を解明することは重要である.

北海道南西部は群発地震がよく起る地域として知られているので, ここに発生した群発地震 に関する資料を整理し，最近渡島半島で観測されたいくつかの微小群発地震について調べたの で報告する。

\section{$\S 2 . \quad$ 過去 80 年間の群発地震活動}

北海道内陸部の群発地震に関する資料収集 [鈴木雄次 (未刊行資料); 久保寺他 (1980)］の 結果によれば，渡島半島を含む北海道南西部は北海道では群発地震の最も頻発する地域であ る. 地震の発生様式を「本震一余震」型, 「前震一本震一余震」型, 「群発」型に分類すること がよくなされるが，ここでは本来の群発型のみならず，時間的・空間的にまとまつて発生した 地震を群発性地震としてとりあげることにした。調べた期間は資料が比較的よく整備されはじ めた 1900 年からで，用いた資料の主なものは，北海道気象月報 (北海道庁)，気象要覧（気 象庁)，北海道地震火山月報（札幌管区気象台）である. 古い時代と近年の資料を統一的に扱 らために, 経験的に次の規準を設定した。 (1) 2 日以内に 2 回以上地震が発生した期間を含む こと, (2) 1 カ月以内に次の地震が発生しなければ活動終息とみなすこと, (3) 活動期間全体の 地震数が 5 回以上であること, (4) 2 回以上の有感地震を含むこと.

この規準により探し出された地震群を Table 1 に，その活動域を Fig. 1 に示す。ここに は主な群発地震だけをとりあげた久保寺他（1980）の表よりさらに多くの地震群が含まれてい る. 古い時代の地震群については個々の地震の大きさについての情報が少ないため「前震一本 震一余震」型か「群発」型かの区別をつけにくいものが多かつたので，ここではこの両者を一 括して，「本震一余震」型との区別だけを示すことにした。地震群はこの地域に一様に分布し ているのではなく，時間的にも空間的にもかなりまとまつて発生していることがわかる，とく に, 渡島大野から厚沢部町館にかけての地域で 1929 年からの 10 年間には地震群の集中がき わめて著しい. 1934 年の八雲町大関 (現在の上八雲), 38 年の渡島大野, 53 年の熊石, の各 地震群は活動の途中で(2)の規準を満す期間があるので, Table 1 では 2 群に分けて示してあ る.このような地震群は一度活動が終つたかに見えるので，その後の活動の見通しをたてる上 で注意が必要になる。

また，ここで採用した地震群の規準には達していないが， 1961 年 4 月から 11 月までの 8 カ月間に江差付近で 8 回の有感地震が発生している.さらに長い期間にわたつて散発的に地 震の発生している所もあり，このような地震活動として宇津（1968）は，(1) 1955 67 年の 松前付近，（2） 1955 67 年の江差一木古内の間，（3） 1953 67 年の函館北方，の各地震活動 


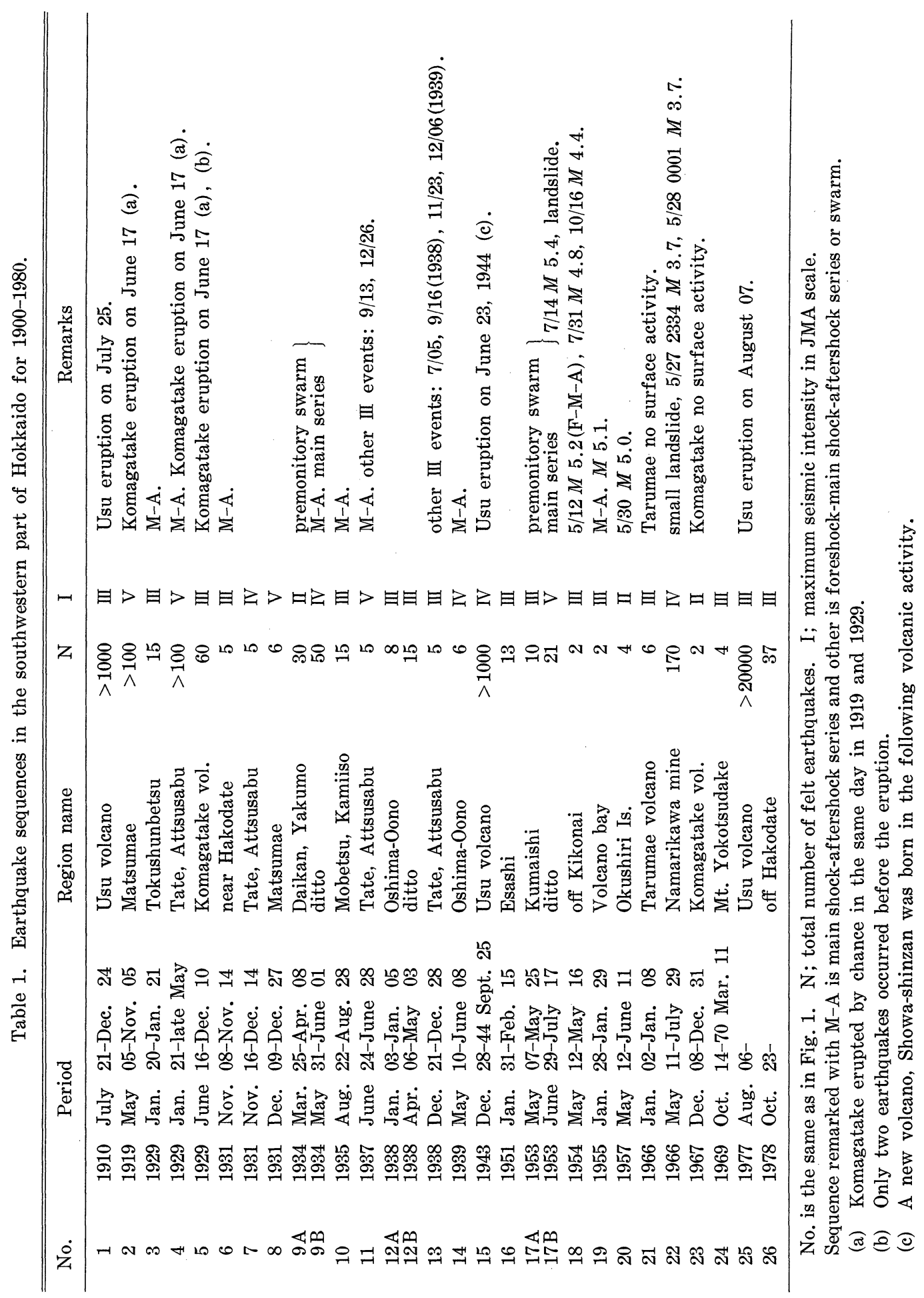




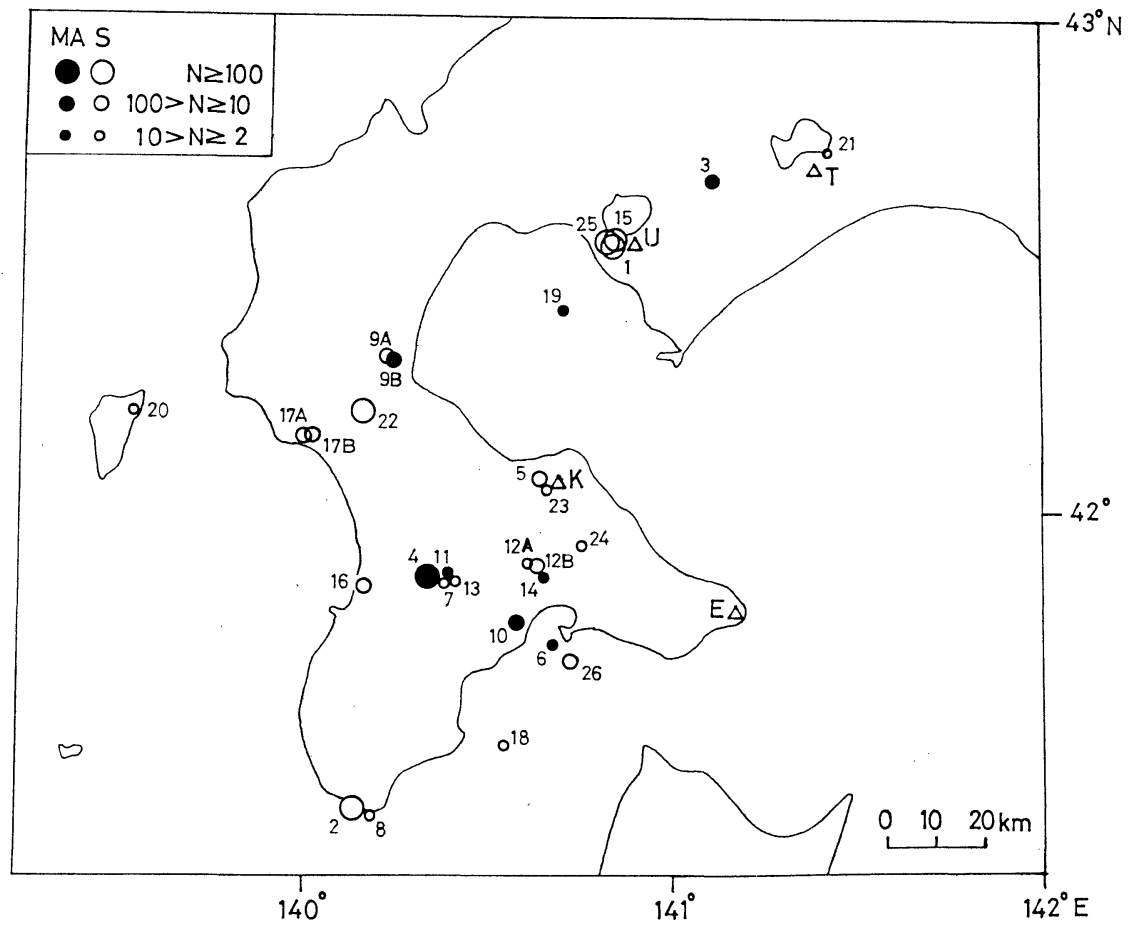

Fig. 1. Earthquake sequences in the southwestern part of Hokkaido for 1900-1980. No. is the same as in Table 1. MA, S, and $\mathrm{N}$ mean main shock-aftershock series, foreshock-main shock-aftershock series or swarm, and total number of feltshocks, respectively. T, U, K, and E show active volcanoes, Tarumae, Usu, Komagatake, and Esan in the order named.

を指摘している，函館北方については， 67 年に駒ケ岳， $69 \sim 70$ 年に横津岳付近に 群発地震 [戸松 (1971) ] が発生しており，その後も散発的な地震活動が続いている [笠原 (1978)].

\section{§3. 最近の地震活動}

\section{1）渡島半島の微小地震活動}

北海道大学理学部の 地震予知観測地域 センター (略称 RCEP) のテレメータ方式による地 震観測が 1976 年 7 月に開始された。その観測とデータ 処理方式についてはすでに報告され ている [KASAHARA（1976）；前田他（1978）］が，渡島半島には茅部郡南茅部町尾札部に恵山 観測点（観測点コード ESH，東経 $141^{\circ} 00^{\prime} 40.3^{\prime \prime}$ ，北緯 $41^{\circ} 53^{\prime} 03.2^{\prime \prime}$ ，高度 $40 \mathrm{~m}$ ） が設置さ れている。この観測点だけで渡島半島全域の地震活動を詳細に把握することは出来ないが，観 測点近傍の地震活動の様子はかなり明らかにされつつあるので以下にそれを示す。

RCEP のルーチン験測の資料を用いて， ESH で $S-P$ 時間が 5 秒以内の地震だけをとり 


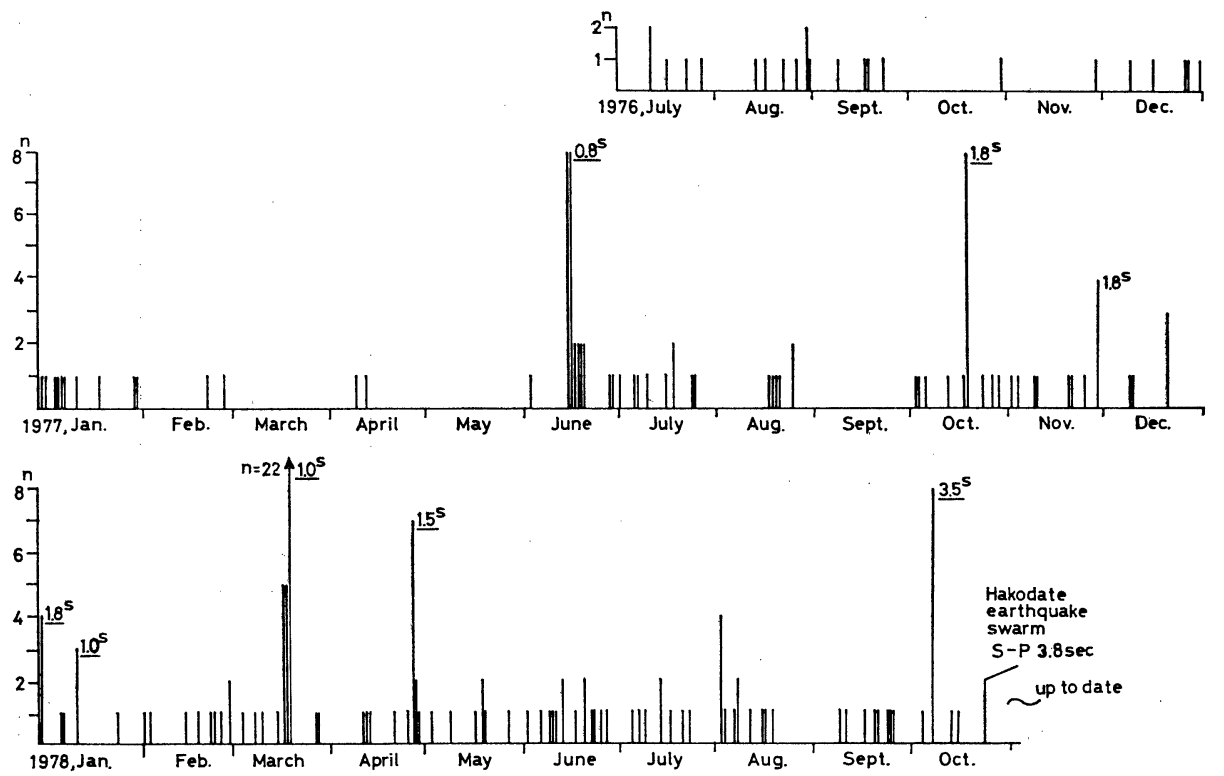

Fig. 2. Temporal variation of daily number of earthquakes with $S-P$ time less than $5.0 \mathrm{sec}$ at ESH. When many events occurred in a sequence, their representative $S-P$ time is shown with an underlined numeral. Detailed data on these sequences are given in Table 2 (except for the one on January 12, 1978). Another paper on Hakodate earthquake swarm will be prepared.

あげた。これは $\mathrm{ESH}$ を中心とする半径およそ $40 \mathrm{~km}$ の円の範囲内の浅い地震を調べること に相当し，もれなく検知される地震の $M$ の下限は 1.5 程度である [鈴木・笠原 (1979)]. 地 震の日別発生頻度を Fig. 2 に示す．かなり短かい時間に明瞭に群をなして地震が発生した場 合には，その群の代表的な $S-P$ 時間の值を記入してある. 1976 年 7 月の観測開始以来約 1 年間の活動は比較的静かであつたが，その後は群発地震活動もみられるようになり，活動はあ きらかに活発になつたことがわかる.ここに示した最後の群発地震活動は 1978 年 10 月 8 日 のものであるが，この活動が収まつた 15 日後の 23 日から函館付近に発生しはじめた微小地 震は顕著な群発地震に発展し，1980 年 10 月現在でもその活動は終息していない。この函館 群発地震に関しては函館市周辺に展開した臨時多点観測網による地震観測が行なわれており， 速報的な結果 [北海道大学理学部 (1980)] と活動初期の報告 [高波他 (1980)] が出されている が，活動全般にわたる結果はあらためて報告する.

\section{2）ESH のデータ処理と観測された微小地震群}

RCEP のルーチンデータ 処理はペン書き記録上でトリガーレベルを超えた地震について行 なわれているが，高密度磁気テープに連続収録されている原データを用いることにより，ルー チンで処理されるより小さな地震まで含めて波形処理も行なうことが出来る. Fig. 2 で $S-P$ 
Table 2. Earthquake sequences observed at ESH during the period from 1977 to 1978.

\begin{tabular}{|c|c|c|c|c|c|c|c|c|}
\hline No. & Date & $\mathrm{N}$ & Duration & $\mathrm{S}-\mathrm{P}$ & $M_{0}$ & Type & $t-n$ pattern ${ }^{*}$ & Remarks \\
\hline $1_{B}^{A}$ & 1977 June $15-18$ & 25 & $3 d 5 h$ & $\begin{array}{l}0.50-0.54 \\
0.83-0.86\end{array}$ & 2.68 & $F-M-A$ & & (1) \\
\hline 2 & 1977 Oct. 20 & 9 & $5 \mathrm{~m}$ & $1.85-1.90$ & 0.69 & $\mathrm{M}-\mathrm{A}$ & & \\
\hline 3 & 1977 Nov. 29 & 17 & $23 \mathrm{~m}$ & 1.85 & 0.70 & $F-M-A$ & & \\
\hline 4 & 1978 Jan. 01 & 6 & $2 \mathrm{~m}$ & $1.85-1.83$ & 0.80 & $F-M-A$ & & \\
\hline 5 & 1978 Jan. 06 & 17 & $10 \mathrm{~m}$ & $1.81-1.87$ & 0.32 & s & & (2) \\
\hline 6 & 1978 Mar. $18-21$ & 97 & $2 \mathrm{dl} 9 \mathrm{~h}$ & $\begin{array}{l}0.82 \\
1.01-1.11\end{array}$ & 3.28 & S & & (3) \\
\hline 7 & 1978 Apr. 28 & 7 & $1 \mathrm{~h} 30 \mathrm{~m}$ & $\begin{array}{l}1.04 \\
1.50-1.51\end{array}$ & 2.50 & $\mathrm{~F}-\mathrm{M}$ & & \\
\hline 8 & 1978 Oct. $8-9$ & 24 & $7 \mathrm{~h}$ & $3.48-3.52$ & 1.80 & $\mathrm{~S}$ & & \\
\hline
\end{tabular}

No. is the same as in Fig. 3. $\mathrm{N}$; number of shocks in each sequence. $\mathrm{M}_{0}$; magnitude of the largest event. $\mathrm{F}$; foreshocks $\mathrm{M}$; main shock. $\mathrm{A}$; aftershocks. $\mathrm{S}$; swarm. *Temporal variation of shocks is shown schematically and dashed part is a premonitory activity.

(1) An event of seismic intensity I (JMA scale) is included. (2) Amplitudes of all events are under the RCEP routine trigger-level. (3) Two events of intensity I are included. Type may be divided into (M-A), (M-A), and (F-M-A).

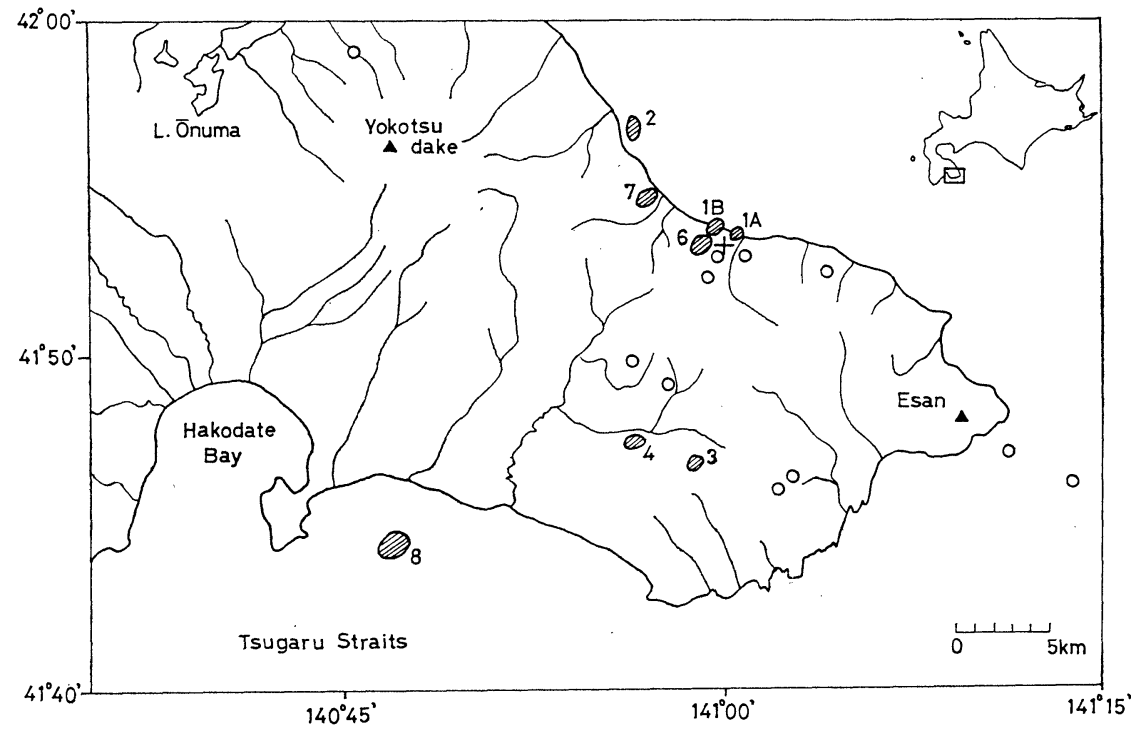

Fig. 3. Location of seismic events in the eastern part of the Oshima peninsula. Hatched ellipse with the same No. as in Table 2 shows an earthquake sequence. Location of the sequence No. 5 is unknown. Open circle shows a single earthquake. These locations are estimated from azimuth and dip angle of incident seismic waves and $S-P$ time at one station ESH (cross).

時間を記入してある地震活動のうち 1978 年 1 月 12 日の活動を除く 7 回の活動と, すべて トリガーレベル以下であつたが原データを利用出来る 1978 年 1 月 6 日の活動を加えた, 計 
Table 3. List of microearthquakes before and after the main shock on June 16, 1977.

\begin{tabular}{|c|c|c|c|c|c|c|c|c|c|c|c|c|}
\hline \multicolumn{3}{|c|}{ Time } & \multicolumn{3}{|c|}{ Initial motion } & \multirow{2}{*}{$\frac{\underset{\mathrm{P}}{\operatorname{Max}}}{358}$} & \multirow{2}{*}{$\frac{\underset{\mathrm{S}}{\mathrm{Amp}}}{358}$} & \multirow{2}{*}{$\frac{S-P}{0.54^{\mathrm{s}}}$} & \multirow{2}{*}{$\begin{array}{l}A_{2} \\
20\end{array}$} & \multirow[t]{2}{*}{$F-P$} & \multirow[t]{2}{*}{$M$} & \multirow[t]{2}{*}{ Remarks } \\
\hline $15^{\mathrm{d}}$ & $09^{\mathrm{b}}$ & $01^{\mathrm{m}}$ & +81 & -47 & -95 & & & & & & & \\
\hline & 11 & 14 & +35 & -23 & -23 & 135 & 113 & 0.54 & 14 & & -1.20 & premonitory \\
\hline & 11 & 15 & $+\mathrm{iP}$ & $-\mathrm{iP}$ & $-\mathrm{iP}$ & & & 0.50 & 46 & & -0.46 & swarm \\
\hline & 12 & 36 & +95 & -68 & -88 & 318 & 412 & 0.50 & 54 & & $-0.40)$ & \\
\hline & 23 & 35 & +1026 & -324 & +351 & & & 0.86 & 594 & $15.5^{\mathrm{s}}$ & 0.83 & \\
\hline \multirow[t]{15}{*}{16} & 02 & 08 & & & & 540 & 432 & 4.2 & & 12.0 & $0.48)$ & \\
\hline & 02 & 08 & & & & 243 & 81 & 4.4 & & 8.5 & $0.01\}$ & other swarm \\
\hline & 02 & 30 & & & & 648 & 432 & 4.2 & & 16.1 & $0.88)$ & \\
\hline & 04 & 39 & & & & 146 & 270 & 0.8 & & 2.0 & -1.92 & \\
\hline & 07 & 11 & +284 & -95 & +135 & & & 0.86 & 95 & & -0.05 & \\
\hline & 08 & 17 & +68 & -18 & & 162 & 203 & 0.85 & 14 & & -1.20 & \\
\hline & 14 & 30 & +567 & -176 & +189 & 1296 & 1836 & 0.85 & 135 & 13.8 & 0.67 & \\
\hline & 15 & 18 & +95 & -24 & +16 & & & 0.83 & 30 & & -0.75 & \\
\hline & 17 & 18 & +23 & $+?$ & +18 & 103 & 130 & 1.82 & 130 & & & single event \\
\hline & 19 & 47 & +108 & -20 & +20 & 223 & 493 & 0.86 & 41 & & -0.55 & \\
\hline & 20 & 38 & $+\mathrm{iP}$ & $-\mathrm{iP}$ & $+\mathrm{iP}$ & & & $(0.84)$ & & & 2.68 & main shock, felt. \\
\hline & 20 & 40 & +19 & -8 & +7 & 45 & 93 & 0.86 & 5 & 1.6 & -2.28 & \\
\hline & 20 & 48 & & & & trace & 95 & $(0.85)$ & 3 & trace & -2.16 & \\
\hline & 20 & 53 & +15 & -5 & & 68 & & 0.85 & 36 & 4.1 & -0.99 & \\
\hline & 23 & 03 & +48 & -14 & +12 & 105 & 127 & 0.86 & 8 & 2.8 & -1.59 & \\
\hline \multirow[t]{7}{*}{17} & 00 & 02 & +9 & -3 & -11 & 22 & 108 & 0.83 & 5 & 2.2 & -1.84 & \\
\hline & 00 & 18 & +24 & -14 & +12 & 74 & 250 & 0.84 & 7 & 3.0 & -1.42 & \\
\hline & 01 & 51 & +500 & -230 & +257 & & & 0.86 & 230 & 12.0 & 0.48 & \\
\hline & 02 & 09 & +88 & -27 & +27 & 203 & 405 & 0.86 & 17 & 3.8 & -1.09 & \\
\hline & 02 & 20 & +389 & -70 & +92 & 918 & & 0.85 & 108 & 10.2 & 0.26 & \\
\hline & 06 & 12 & & & & 43 & 97 & 0.8 & & 4.8 & -0.77 & \\
\hline & 14 & 37 & & & & 146 & & & & 9.- & -0.09 & \\
\hline \multirow[t]{3}{*}{18} & 04 & 32 & & -20 & & 41 & 46 & 0.83 & 20 & & -1.96 & \\
\hline & 12 & 28 & +34 & & +34 & 270 & 149 & 3.27 & & & & single event \\
\hline & 13 & 46 & +105 & -26 & +24 & 203 & & 0.84 & 68 & & -0.26 & \\
\hline
\end{tabular}

Unit of amplitude is $\mu$ kine. $A_{2}$ is amplitude of UD component after 2 seconds from $\mathrm{P}$ arrival time. Magnitude $M$ is roughly estimated from $F-P$ and/or $A_{2}$.

8 個の地震群について, 各群の活動様式, 空間分布, 規模別分布, 振幅（波形）の時間変化な どについて調べた。これらの地震群には RCEP 観測網で震源決定が出来るほど大きな地震は 含まれていなかつたので，ESH 1 点の 3 成分記録から得られる $\mathrm{P}$ 波群の方位角と入射角 [前 田 (1978) ] にS-P 時間を組合せて震源域を推定した. 調べた地震群を Table 2 に, その活 動域を Fig. 3 に示す. なお，いくつかの単発地震の位置も Fig. 3 に入れてある.

\section{3) 各地蜄群の特徵}

Table 2 の地震群についてその特徵をのべる. 以下では, 1 つの地震群中の地震をマグニチ ュードの大きい順に $M_{0}, M_{1}, M_{2}, \cdots$ として示す.

(1) 1977 年 6 月 15 日 18 日の地震活動 
1977 年 6 月 16 日 20 時 38 分に南茅部町できわめて局地的な有感地震が発生した. $M_{\mathrm{KMU}}$ $=2.7$ の微小地震であつたが, 海岸沿いに約 $10 \mathrm{~km}$ にわたつて急激な地震動と振動音を感じ ている [高波他 (1977)]。この地震の前後の 6 月 15 日から 18 日までに ESH で観測された S-P 時間 5 秒以下の地震の験湘結果を Table 3 に示す. 20 時 38 分の有感地震には影著な 前震活動と余震活動があり, 17 日 00 時 02 分の地震以外はすべて, 初動方向からみて ESH の北西側に震源域があつたことがわかる. 前震と余震の $S-P$ 時間は $0.83 \sim 0.86$ 秒の範囲に あり分布幅は 0.03 秒しかないから震源域の 拡がりは $300 \mathrm{~m}$ を超すことはないであろう. 15 日には $S-P$ 時間が $0.50 \sim 0.54$ 秒にはいる地震 4 個が発生しているが，これらの震源域は ESH の北東側にあつて， 約 15 時間後にはじまる「前震一本震一余震」型の活動とは明らか に別の場所での活動であつた (Fig. 3 の No. 1A と 1B). しかし，時間的・空間的にきわめ て 接近して 発生しているので, 15 日の 4 個の地震はその後に続く主活動の「前駆的（群発） 地震」活動とみなしてもよいものであろう。主活動がはじまつてからは， $S-P$ 時間が 0.5 秒 台の地震は全く発生していない。

(2) 1977 年 10 月 20 日と 11 月 29 日の地震活動

1977 年 10 月 20 日と 11 月 29 日には $S-P$ 時間がいずれも 1.85 秒程度の地震が続発 したが, 前の活動域は ESH の北西側にあつたのに対して, 後のそれは南側にあつて, 明らか に違つた場所での活動であつた（Fig. 3 の No. 2 と 3)。また, 10 月の活動には前震は観測 されず「本震一余震」型であつたのに対して，11 月の活動は「前震一本震一余震」型であり， 活動様式の点でも違がつたものであつた（Fig. 4 の No. 2 と 3). 11 月の活動はこれまでに 指摘されている前震の特徵をそなえていたことがわかる：地震の規模別度数分布の特性を示す パラメータ $b$ 值について, 前震の $b$ が余震の $b$ より小さい例 [SUYEHIRO et al. (1964)] が知られているが, No. 3 の地震群では, 本震 $M_{0}$ 以前に は $M_{1} \sim M_{4}$ の大きな地震が発生して いるのに対して, 本震以後は $M_{5}$ 以下 の小さな地震しか発生していないか ら, 前震は余震にくらべて明らかに大 きい地震から構成されていて, 前震の $b$ が小さいことと定性的には同じ傾向 を示している，また，前震活動の最盛

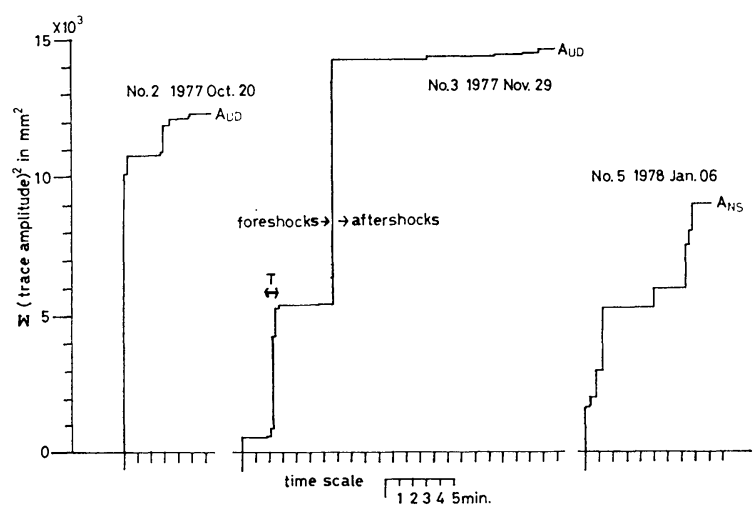

Fig. 4. Cumulative square of maximum amplitude against time. Seismograms of shocks occurred in the time interval denoted with $\mathrm{T}$ are shown in Fig. 5. 
期がすぎてから本震が発生する例 [許 (1976)] が知られているが， No. 3 の地震群では本震 の 7 分前から始まつた前震活動は急激に 活発になつた後，4 分ほどの静かな時間を和いて本 震が発生した (Fig. 4 の No. 3).

(3) 1978 年 1 月 1 日と 1 月 6 日の地震活動

前震活動のもら一つの特徵として本震 $M_{0}$ に近づくにつれて前震の発生間隔は短かくなり 振幅は大きくなつてゆく例 [本谷 (1969)] が知られている. 1978 年 1 月 1 日には 2 分間に 6 個の地震が続発したが，これらの地震は明らかに「前震一本震一余震」系列をなして和り， 前震は 2 個だけであるが，本震 $M_{0}$ に近づくにつれて発生間隔が短かくなり，振幅は大きく なつてゆく特徴を示していたことが注目される (Fig. 5 の No. 4). しかし, 1977 年 11 月 29 日の地震群の場合には, 2 番目に大きい地震 $M_{1}$ の前に同じ特徴を示す地震系列がみられ た (Fig. 5 の No. 3) が，このときは 4 分後にさらに大きい地震 $M_{0}$ が発生し，さきにのべ たように全体は「前震一本震一余震」型の活動となつた。 また， 1978 年 1 月 6 日にもほと んど同じ $S-P$ 時間の地震が続発したが，大変小さい地震ばかりであつたので， 1 月 1 日の

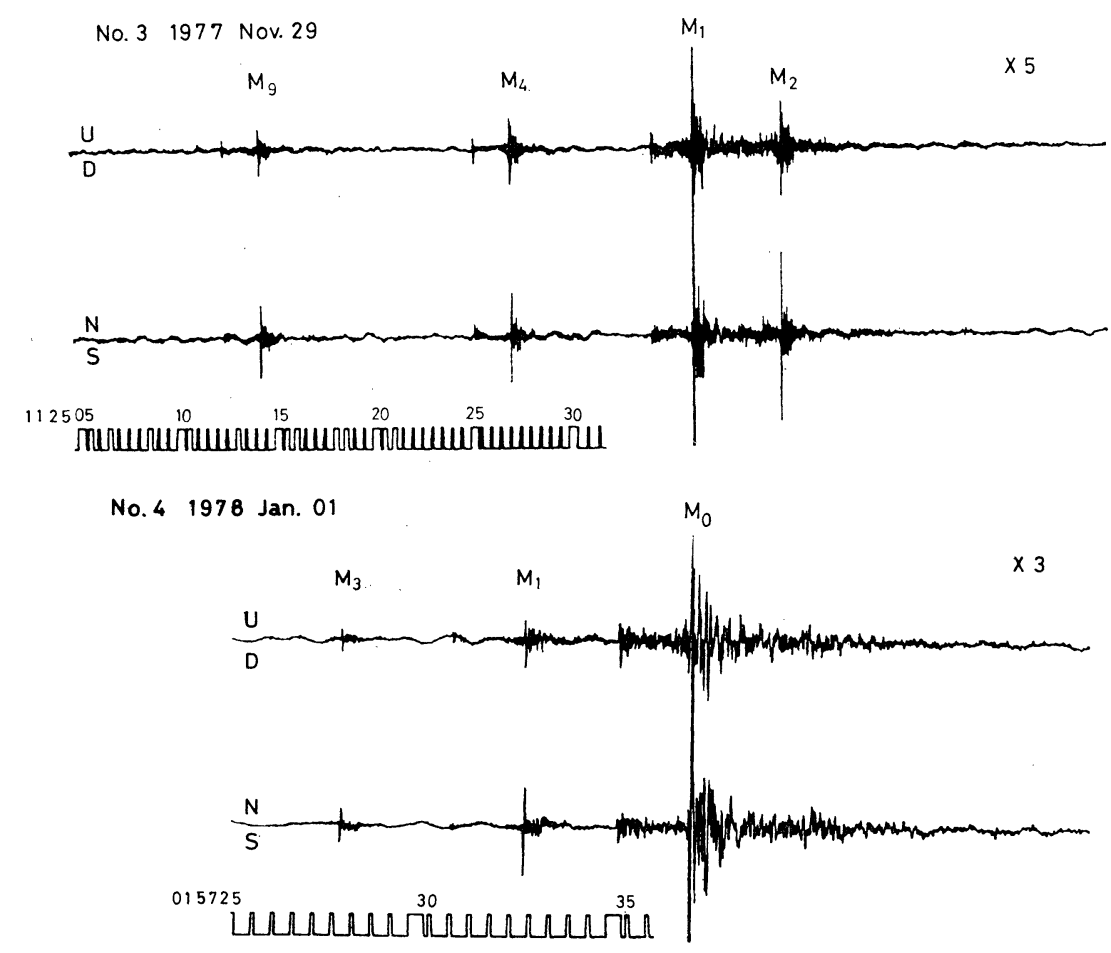

Fig. 5. Seismograms of two earthquake sequences. $M_{0}$ is the largest and $M_{i}$ is the $i$-th successive largest event in each sequence. $\mathrm{X} 3$ and $\mathrm{X} 5$ are magnification factors on CRT display from the original HDDR magnetic tape. 


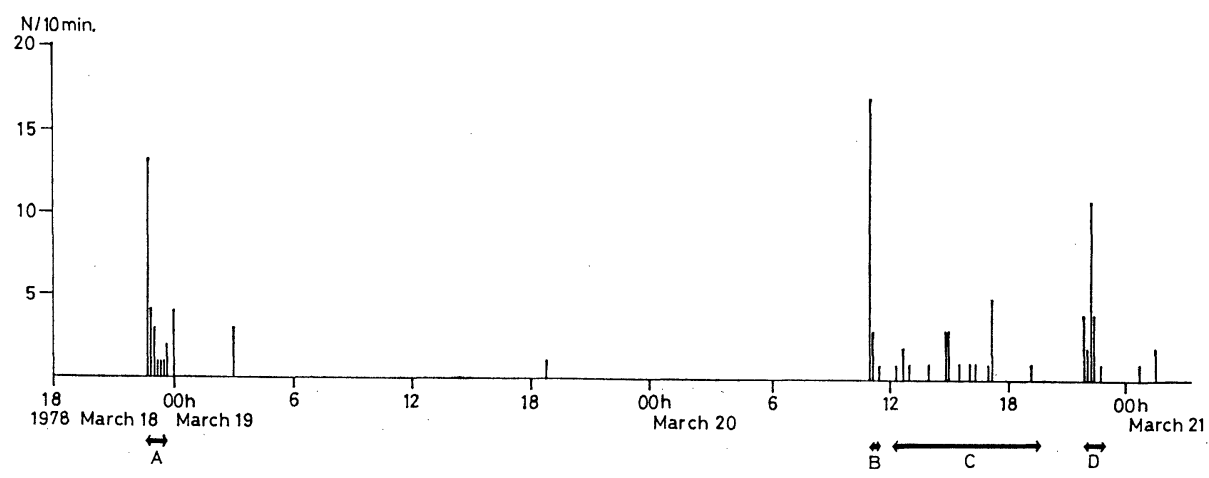

Fig. 6. Temporal variation of number of events in the complex sequence No. 6. A and B: main shock-aftershock series started with feltshock near ESH at $22 \mathrm{~h} 47 \mathrm{~m}$, March 18 and $11 \mathrm{~h} 03 \mathrm{~m}$, March 20, respectively. All other events are unfelt. C: transient seismic activity. D: foreshock-main shock-aftershock series started at $21 \mathrm{~h} 57 \mathrm{~m}$, with main event at $22 \mathrm{~h} 20 \mathrm{~m}$, March 20 .

ものと同じ場所での活動かどらかは確かめられなかつた。しかし，6 日のものは活動様式とし ては典型的な「群発」型 (Fig. 4 の No. 5) で, 1 月 1 日のものとは明らかに違つていた.

(4) 1978 年 3 月 18 日 21 日の地震活動

1978 年 3 月 18 日から 21 日にかけて発生した地震群は今回調べた中では最も規模が大き く, 南茅部町で有感の地震が 2 回含まれている. 全体は, 18 日 22 時 47 分の有感地震 $\left(M_{1}\right.$ $=2.68)$ に続く「本震一余震」型, 20 日 11 時 03 分の 2 回目の有感地震 $\left(M_{0}=3.28\right)$ 飞続 く「本震一余震」型, 12 時 19 時の過渡的地震活動, 21 時 57 分から始まる明膫な「前震一 本震一余震」型（この中の最大地震（ $M_{2}=2.15 ）$ は 22 時 20 分）の 4 つの活動 (Fig. 6) よりなり，各々の活動域はあきらかに違つていたことがわかる (Fig. 7). この違いはこの領 域の破壊過程に関連していると考えられるがこれに関する考察はあらためておこないたい。 た，18 日 08 時頃より，近いけれぞも明らかに異なつた場所で「前駆的地震」活動が認めら れた。このうち震源位置の推定されたものが Fig. 7 の $\mathrm{f}$ で深さはその後の主活動の地震より 浅かつたと思われる。

(5) 1978 年 4 月 28 日の地震活動

1978 年 4 月 28 日にみられた活動は「前駆的地震」活動につづいて, 主活動の最後に最大 地震が発生したもので, いわば「前震一本震一(余震なし)」ともいうべき活動様式を示した. 検知能力以下の微小余震は発生していたかも知れないが，もしあつたとしても前震より小さな ものばかりであつたことは確かである.

(6) 1978 年 10 月 8 日 9 日の地震活動 
1978 年 10 月 8 日の活動は典型的な群発地震とみなし得るものであつた. この地震群につ いては, $\mathrm{P}$ 波群の上下動最大振幅 $A_{\mathrm{PV}}$ と $\mathrm{S}$ 波群の水平動 ( $\mathrm{EW}$ 成分) 最大振幅 $A_{\mathrm{SE}}$ との比 $A_{\mathrm{PV}} / A_{\mathrm{SE}}$ の值が地震活動が活発になるにつれて大きくなつてゆく傾向がみられた (Fig. 8). S 波群の NS 成分をとつても同じであつた。 $A_{\mathrm{PV}} / A_{\mathrm{SN}}$ の異なつている記象例を Fig. 9 (A) に 示す. 78 年 1 月 6 日の活動も「群発」 型であつたが，このときは $A_{\mathrm{VP}} / A_{\mathrm{SE}}$ は 0.04 0.35 の間にあり $\mathrm{P}$ 波群の小 さい地震ばかりで, 地震数が少なく活 動期間も短かつたせいか, 振幅比の時 間变化に一定の傾向はみられなかつ た。すでにのべたように 10 月 8 日の 活動が終息して 15 日後の 23 日から 函館群発地震が発生しはじめたわけで あるが，8 日の地震群の活動域は函館 群発地震のそれとは近いけれども異な つた場所にあると思われ，地震波形も 函館群発地震活動の初期のものとは著 しく異なつていた（Fig. 9 の（A) と (B)). しかし，函館群発地震の「前駆 的群発地震」活動とも考学られるる ので，注目すべき地震活動であつたと いえる.

\section{§4. 考察}

1900 年以降の 北海道南西部 の地殼 活動（地震活動と火山活動）を調べた 結果， 1930 年代に 活動のピークがあ り，最近再び活動が活発化してきてい ることがわかつた，以下では，この地 域の地殼活動の特性とこれに関連する いくつかのことについてのべる.

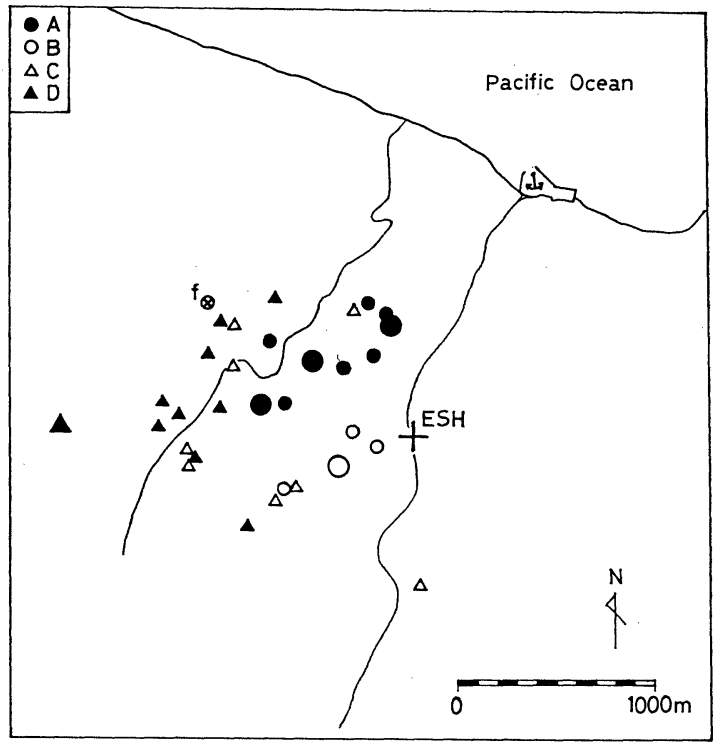

Fig. 7. Spatial distribution of earthquakes in the sequence No. 6. f: event at $08 \mathrm{~h} 11 \mathrm{~m}$, March 18, one of the premonitory events. Refer to Fig. 6 for $\mathrm{A}, \mathrm{B}, \mathrm{C}$, and D. The largest events in the sub-series $A$ and $B$ are not located because their initial motions are over the dynamic range of the RCEP observation system.

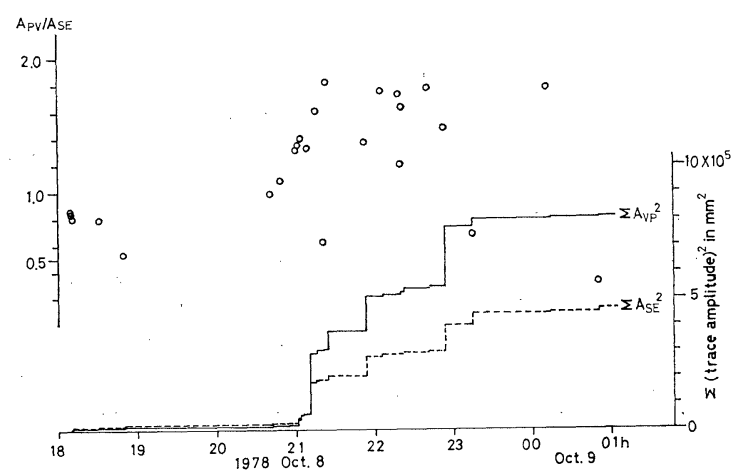

Fig. 8. Cumulative square of maximum amplitude and amplitude ratio of $\mathrm{P}$ and $\mathrm{S}$ waves against time for the sequence No. 8. 


\section{1）地震活動の時間的・空間的特性}

有珠山付近には顕著な群発地震活動 が 1910 年と $43-44$ 年にあり, 77 年 8 月からほぼ同じ場所ではじまつた群 発地震活動は現在も続いている. 78 年 10 月からはじまつた函館群発地震 もまだその活動は続いているが，この 付近には 1931 年に「本震一余震」型 の地震活動があつたＥSH で観測さ れる $S-P$ 時間が 10 秒以内の地震を 用いて，過去に顕著な群発地震活動が みられた領域の現在の地震活動を調べ たが，有珠山，函館付近の活動以外に は，これまでのところ目につくほどの 活動は見つかつていない．宇津 (1968) は渡島半島を含む北海道南西部の地震

(A)

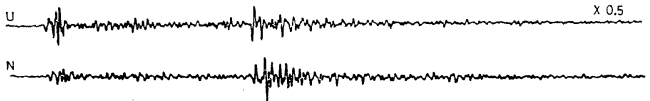

Oct. 82145

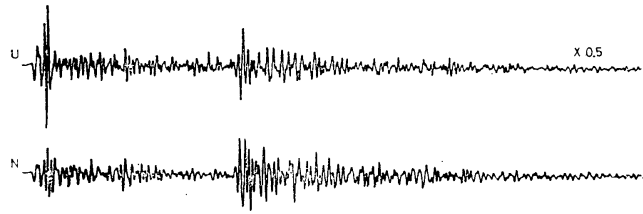

(B) Oct. $25 \quad 1325$

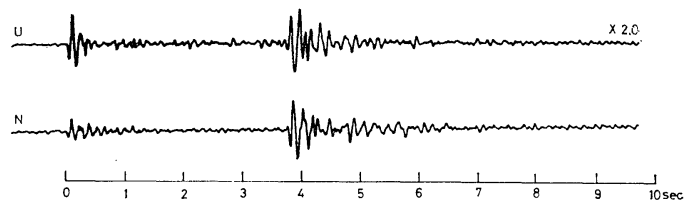

Fig. 9. (A) Example of seismograms of the sequence No. 8.

(B) Seismogram of Hakodate earthquake swarm at early stage of its activity. X0.5 and X2.0 are magnification factors on CRT display and time scale is common.

活動の特性の一つとして，ある地域に発生する群発地震は比較的短かい期間にまとまつて発生 し，その期間以外にはほとんど起さていないことを指摘している．§2 でのべた渡島大野から 館にかけてはそのような地域と考兄られ，1930 年代に群発地震が集中的に発生したが，その 後は全く静かな状態が続いている。また，寿都付近に 1959 年から 1973 年までときどき起き ていた地震 [宇津 (1968)，本谷 (1975)] は，その後は全く発生していない。このような場所 での地震活動の全体像を理解するにはかなり長期にわたる観測が必要であろう.

\section{2）群発地震と火山活動の関連}

有珠山の 火山活動とそこに起る群発地震との関係 [気象庁 (1980)] はよく知られている. 駒ケ岳については有珠山の場合ほど直接的ではないが，以下にのべる事例は群発地震と火山活 動との関連を暗示していると思われるので，今後も注意しておくべきことであるう．Table 1 に示されているょうに，1919 年の駒ヶ岳の噴火では同じ年に 松前で群発地震が発生している し，1929 年には厚沢部町館で「本震一余震」型の地震活動があつた後，駒ケ岳が噴火し，駒 ケ岳付近にも群発地震が発生している，その後, 駒ヶ岳の火山活動は，1934，35，37，38, 42 年に知られて和り，渡島大野から館にかけての地域で群発性地震が頻発した時期に一致してい る. 1942 年以降は駒ヶ岳は火山活動をしていないし，いまのべた場所での 群発性地震活動も 


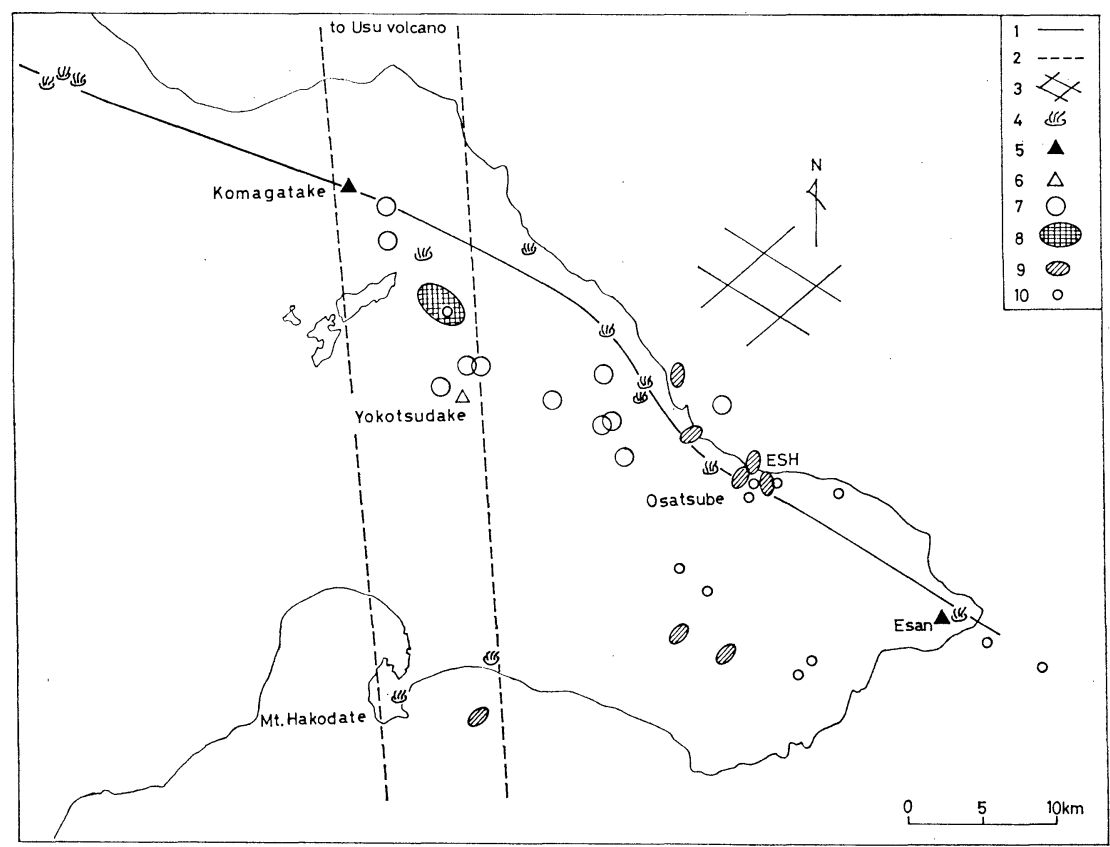

Fig. 10. Seismotectonic map in the eastern part of the Oshima peninsula. 1: geotectonic line, 2: volcanotectonic line, 3: two prominent directions of fracturing in this region, 4: hot spring, 5: active volcano, 6: extinct volcano [after Kато (1909) ]. 7: epicenters by Sapporo Meteorological Observatory for 19671970 (two events near Komagatake were relocated by the author). 8: microearthquake epicenters for August 11-September 05, 1970 [after Tomatsu (1971)]. 9 and 10: refer to Fig. 3.

知られていない.

3) 渡島半島のテクトニックスと地震活動

$\S 3$ で調べた微小群発地震活動のみられた地域は，北海道の地形区分 [瀬川 (1974)] では駒 ケ岳火山地域としてまとめられており，駒ヶ岳（活火山），横津岳（鮮新世末期あるいは第四 紀はじめに噴出した死火山), 恵山（活火山）が，この順に北西一南東方向に並んでいて，地 形の特徵，温泉分布の配列などから，この方向に走る 構造線の存在が 考えられている[加藤 (1909)]. §2 で示したように, 駒ケ岳から横津岳にかけての地域には顕著な群発地震が発生し たこともあり地震活動は高い. Fig. 10 に示すように，横津岳と尾札部の間にはこれまでいく つかの地震の発生が知られているから，今回観測された ESH 付近の微小群発地震活動がこれ に連らなるものとすれば，北西一南東に走る構造線に関連して地震活動の高い地域が駒ら岳か ら尾札部付近まで続いていて，その中で尾札部付近の活動が最近とくに活発になつたと考える ことが出来る．構造線は尾札部から恵山まで続いていると推定されているが，この部分にはこ 
れまでのところ地震活動はほとんど知られていない。

\section{4）地震活動と地殼応力の状態}

地震活動は長い時間スケールのテクトニックスに関連しているだけでなく, 地震が発生して いる場の現在の応力状態も反映しているはずである. MOGI (1963) は地震発生場の応力集中の 程度が増大するにつれてそこで発生する地震系列の活動様式が「本震一余震」型から「前震一 本震一余震」型を経て「群発」型へ移行することをぜい性試料を用いた破壊実験の結果から類 推し, 広域的に一様な応力場にあるときは地殼の破砕度の大きい所ほど応力集中を起しやすい と考えて, 日本列島の地殼の破砕度の地理的分布を示した. それによると, 前震を伴う地震お よび群発地震がしばしば発生する渡島半島は破砕度の大きい地域として分類されている。この 考えによれば，§3 で調べた微小地震活動は渡島半島東部の比較的狭い地域に 発生したものば かりであるのに，あらゆる型の活動様式がみられたことは応力集中の程度の異なつている領域 が狭い地域に混在していることになる．各群の活動様式を活動域（Fig. 3) に対応させてみる と， ESH 付近に発生した No. 1，6，7 の各群には共通して「前駆的地震活動」がみられた し, ESH 南方の No. 3 と 4 の活動は共に「前震一本震一余震」型であつた. MOGI (1963) の用いた資料は多数の有感地震を含む規模の大きい地震群であつたが，ここで調べた地震活動 は有感地震を含んで 3 日程度続くものから微小地震ばかりで全体の活動が数分で終るものまで におよんでいる。これまで「本震一余震」型と思われていた活動でも, 検知能力の高い観測を 行ならと, 前震が観測されて「前震一本震一余震」型の活動であることが判明することも考兄 られる. ESH の高感度地震計による連続観測によつて, このような地震活動の様式がほぼ連 続的にとらえられたことは地凯の応力状態を詳細に知る可能性を示したものといえる. これま でのところ同じ活動域と認められる所に繰返し発生した活動で詳細な観測資料の得られている 例はないケれども，地震活動様式が応力状態を反映しているとすれば，地震活動の監視を続け ることによつて地壳浅部の応力状態の時間的・空間的変化を知ることが出来ると考えられる.

\section{5) 内陸の地震活動と広域応力場}

1968 年十勝沖地震 $(M 7.9)$ の直後に十勝岳付近に火山性地震が発生し, 一時的に十勝岳 付近の地震活動が活発となつた [気象庁 (1969)]. また, 東北地方においては, 1978 年 2 月 20 日（M 6.7）抽び 6 月 12 日（M 7.4）の宮城県沖地震の直後に震央から約 $100 \mathrm{~km}$ 離 れた川渡および釜房において微小地震が群発した [東北大理学部 $(1978,1979)$ ]. これらの事 例は海溝付近で大地震の発生によつて生じた応力場の急激な変化が内陸地域にまで影響を及ぼ し, 地震活動を誘発したと考えられる. しかし, 今回調べた群発地震群に関しては, 顕著な地 震に直接関連していると思われるものはなかつた. 
北海道周辺の大地震と内陸部の浅発地震活動との関係を調べた鈴木雄次 (1976) は両者の間 にははつきりした因果関係は見出されないとしながらも, 北海道周辺の海域の大地震は内陸部 の地震活動の最盛期よりもその末期また初期に発生している傾向があるとのべている．鈴木・ 広田 (1973) は北海道東部弟子屈地方の浅発地震活動と海溝付近の大地震発生との関連をさら に積極的に論じ, この地方の浅発地震は北海道東部に地殼変動をももたらす広域的なテクトニ ックストレスによつて起されると考えている. ここでは, 内陸に発生する個々の群発地震と大 地震との直接の対応を考えるよりも, 地震活動の特性を広域的に時間の経過とともに考える見 方に立つて, 1930 年代の北海道南西部の地殼活動の活発化 (群発性地震の頻発, 火山活動), 1940 年代の日本海の浅発地震活動（積丹沖で 1940 年と 47 年にともに $M 7.0$ の地震発生） につついて, 1952 年十勝沖地震 $(M$ 8.0) が発生したことに 注目しておきたい. 十勝沖地震 の再現期間を 80 年程度と考えると, 1952 年から数えて 1 サイクルの $1 / 3$ 程度の時間は既に 経過したことになり，KATSUMATA and YoSHIDA（1980）は 1974 年頃から震源域での地震 活動が新しい段階に入つたのではないかと考えている. 次の十勝沖地震の前にも同じことが繰 返されるという確証はないけれども, 尾札部付近での 微小群発地震の頻発, 有珠山の火山活 動, 樽前山の火山活動 [勝井他 (1977)], 函館群発地震とつつくく, 北海道南西部の地壳活動の 最近の活発化が，KATSUMATA and YoSHIDA (1980) のいう52 年十勝沖地震の震源域で地震 活動の変化が始まつたとする時期に呼応している可能性もあるので, 今後のこの地域の地震活 動に注意しておく必要がある.

植木他（1980）によつて東北地方についても §2 で採用したのとほぼ同じ規準で群発性地震 に関する資料の収集・解析が行なわれていて，1926 年以降 78 年までの 53 年間に 31 回の 活動が報告されている，北海道南西部においては同じ期間で 24 回であるから, 対象地域の面 積の違いを考慮すると, 群発性地震活動の発生頻度は両地方でほぼ同じ程度とみられる. 東北 地方においても 1930 年代に群発性地震発生頻度のピークがあつた後, 1978 年にも小さなピ 一クが見られること[植木他 (1980)], 東北地方北部の広範囲にわたり起震歪力のレベルが最 近高くなつていると思われること[佐藤他（1980)]は，これまでのべてきた北海道南西部の地 震活動の状況と大変良く符号している．このことは北海道南西部と東北地方北部は基本的には 同じ地学的場の中にあることを示唆しているし，ある地域の地震活動をより広域的な観点で考 觉る立場を支持しているといえよう。

\section{§5. おわりに}

北海道南西部の群発地震に関する資料を整理するとともに, 北海道大学理学部地震子知観測 
地域センターの高感度地震観測網で観測されたいくつかの微小群発地震活動について調べた。 地震群の発生様式をとの群に含まれる地震の空間分布，規模別分布，地震波形の変化などに 関連させて調べたが，活動様式との間に共通した特徴は見つからなかつた。これまで大きな地 震の前震活動について知られているいくつかの特徴を, 微小前震群でも少なくとも形式的には そなえている場合もあることが確められた。いくつかの地震群については主活動と時間的・空 間的にきわめて接近した「前駆的地震」活動が明瞭に認められたが，地震数が少ないこともあ つて，前駆的活動とそれに続く主活動との関連を定量的に調べるにはいたらなかつた.

内陸に発生する直下型地震に関連してその付近の微小地震活動の状況に変化があらわれるか も知れないし，内陸の微小地震活動はその場所だけの現象ではなく, 海溝付近の大地震の発生 にもかかわる広域的な応力場の状況を反映していることが示唆されたので，これまでの地震活 動の特性を明らかにして打くとともに，今後とも地震活動の監視を続けてゆくことが重要であ る.

群発地震の資料收集は，自然災害科学研究資料解析班の中に設けられた群発地震に関する資 料収集グループの研究の一部として行なわれた。このさいに，鈴木雄次氏（気象庁地震情報資 料室）がとりまとめられた未刊行資料ファイルによるところが多大であつたことを記して感謝 致します。この稿をまとめるにあたり有益な助言を頂いた北海道大学理学部地震予知観測地域 センターの鈴木貞臣博士と貴重な観測資料を提供して頂いた 同センターの諸氏に感謝致しま す。データ処理は同センターの MODCOMP IV による処理システムによりました.

\section{文献}

北海道大学理学部, 1980, 函館付近の群発地震活動（続）, 地震予知連絡会報， 24，6-7.

Kasahara, M., 1976, Seismic and Geodetic Observations through the PCM Telemetering System in Hokkaido, Japan, J. Geod. Soc. Japan, 22, 292-294.

笠原 稔, 1978, 函館付近の地震活動 (I), 北大地震予知センタ一速報, 4, 31-33.

加藤武夫，1909，北海道駒ヶ岳火山地質調査報文，震災予防調査会報，62，1-64.

勝井義雄・大沼晃助・新井田清信・鈴木建夫・近堂祐弘，1979，樽前山 1978 年 5 月の噴火，火山，24, $31-40$.

Katsumata, M. and A. Yoshida, 1980, Change in Seismicity and Development of the Focal Region, Pap. Met. Geophys., 31, 15-32.

気象庁，1969, 十勝沖地震後の十勝岳に打数地震活動について, 気象庁技術報告, $68,38-47$.

気象庁, 1980, 有珠山噴火活動調查報告, 気象庁技術報告, 99, 4-6.

久保寺 章・内池浩生・本谷義信・植木真人・茅野一郎, 1980 , 群発地震目関する資料収集解析 (第 2 報), 自然災害資料解析, $7,67-78$.

前田 亟, 1978, 続 波形解析プログラム，北大地震予知センタ一速報，3，23-26.

前田 亟・本谷義信・鈴木貞臣, 1978, 北海道大学の地震地殼变動テレメータデータ 集録および 処理シス テムについて, 地震, 31，401-413.

MoGI, K., 1963, Some Discussions on Aftershocks, Foreshocks and Earthquake Swarms-the Fracture of a Semi-infinite Body caused by an Inner Stress Origin and Its Relation to the Earthquake Phenomena (Third Paper), Bull. Earthq. Res. Inst., 41, 615-658. 
本谷義信, 1969,1969 年 8 月 12 日根室東方沖地震の余震活動, 北大地球物理研究報告, 24, 93-106.

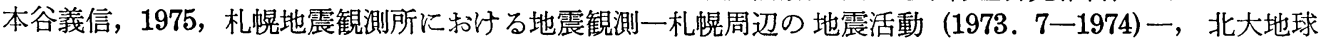
物理研究報告, 34,55-65.

佐藤魂夫・田中和夫・佐藤 裕, 1980 , 東北地方北部における最近の 地震活動と 起震歪力場, Sci. Rep. Hirosaki Univ., 27, 33-45.

瀬川秀良, 1974, 日本地形誌 北海道地方, 朝倉書店, 213-222.

鈴木貞臣・広田知保, 1974, 北海道東部抢よびその周辺の地震活動（1)一弟子屈・阿寒地域の浅発地震一, 地震, 26, 77-92.

鈴木貞臣・笠原 稔, 1979 , 地震テレメータの検知能力, 北大地震予知センタ一速報, 5, 57-60.

鈴木雄次, 1976, 北海道内陸部の浅発地震活動について，地震予知連絡会報，16，11-15.

SuYeHiro, S., T. Asada, and M. OHTARE, 1964, Foreshocks and Aftershocks Accompanying a Perceptible Earthquake in Central Japan, Pap. Met. Geophys., 15, 71-88.

高波鉄夫・岡山宗夫・南茅部町役場, 1977,1977 年 6 月 16 日南茅部町有感地震 $(M 2.7)$, 北大地震予 知センター速報, $2,38-41$.

高波鉄夫・島村英紀・本谷義信，1980，函館群発地震初期の地震観測，地震，33，269-287.

東北大学理学部，1978, 1978 年 2 月 20 日の宮城県沖地震, 地震予知連絡会報, 20, 16-21.

東北大学理学部, 1979,1978 年 6 月 12 日宮城県沖地震, 地震予知連絡会報, 21, 55-59.

戸松征夫, 1971, 北海道駒ヶ岳周辺の地震活動 (1969-1970), 北大地球物理学報告, 26, 85-98.

植木貞人・立花憲司・高木章夫, 1980 , 東北地方に拈ける群発性地震の 活動とその特性, 東北地域災害科 学研究報告, 16, 44-47.

宇津徳治, 1968, 北海道およびその周辺の地震活動, 北大地球物理研究報告, 20, 51-75.

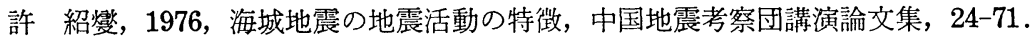

